\title{
午ミカルス覚え書き
}

\section{ドコサヘキサエン酸 (DHA)}

\section{矢 澤 一 良*}

\section{Docosahexaenoic Acid}

Kazunaga YazAwA*

DHA は近年その特異な生理活性が注目されるように なった高度不飽和脂肪酸の一種である ${ }^{1)}$ 。

\section{1. 製 法}

DHA は合成がきわめて困難な脂肪酸であり, その分 子構造は図 1 に示すように all-cis で二重結合を 6 個所 有する炭素数 22 の脂肪酸である。したがってここでは 合成法を述べることはできないので, 天然物からの抽 出・精製法について概要を述べる。

まずDHA 含有量の高い天然素材, 例えばカツオ油, マグロ油等を使うことが必要となる。DHA はエチルエ ステルとした方が分離精製が簡単であるため, 魚油エチ ルエステルを得る。分子蒸留等により $C_{22}$ 留分を得た後, 尿素付加法により高度不飽和画分を得る。本工程で得ら れた純度 $80 \%$ 以上の DHA エチルエステルは, さらに 医薬品レベルまでに高純度化される。有機化合物に不飽 和結合を有する場合, 銀イオンは $\pi$ 錯体を形成するこ とが知られており，さらに二重結合度によりその錯体形 成能に差が生じ，この性質を利用することにより， DHA は物理的性質の近似する EPA と分離することが可 能となる。銀イオン交換粘土鉱物を用いたカラムクロマ トグラフィー法 ${ }^{2}$, および硝酸銀溶液を用いた液一液分 配法 ${ }^{3)}$ が知られているが, 詳細は各論文を参照されたい。 DHA は医薬品開発に先立ち, 食用油に精製されたも のが機能性健康食品として普及してきている。純度は 25 50\% 程度のグリセリド型の食用油は, 通常の脱臭 脱色工程を経た後, 分子蒸留法や水蒸気蒸留法により特 有の魚臭や不瞼化物等の不純物を除去することにより得

* (財)相模中央化学研究所

口)

* Sagami Chemical Research Center

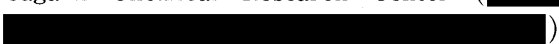

られる。

前者の高純度 DHA は，ハリマ化成(株)および(株)資 生堂が製造している。後者の食用 DHA 高含有油は, マ ルハ(株), 日本水産(株), ハリマ化成(株), 日本油脂(株), 日本化学飼料(株)等十数社により供給されている。高純 度品は高価であるため, 需要はまだまだ少ないが将来医 薬品として開発・大量生産される可能性が高い。食用油 は年間数百トンレベルで生産されている。

\section{2. 性 質}

DHA は透明なかすかに黄色を呈する油状物質であり 融点は $-44.5 \sim-44.1^{\circ} \mathrm{C}, n_{D}{ }^{26}=1.5017$, 分子量は 324 $\left(\mathrm{C}_{22} \mathrm{H}_{32} \mathrm{O}_{2}\right.$, 化学構造は図 1 参照 $)$, ヨウ素価 446 を示す。 赤外吸収スペクトルを図 2 に示す。紫外部吸収は 220 〜 400 nm での特徴的な吸収はみられない。

酸化安定性が悪いため, 保存は不活性ガス気流下が望 ましい。また熱や紫外線照射により重合体やトランス型 への変換も知られている。

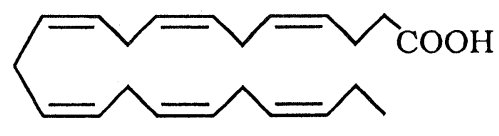

cis - 4,7,10,13,16,19-Docosahexaenoic Acid

Fig. 1 DHA の化学構造

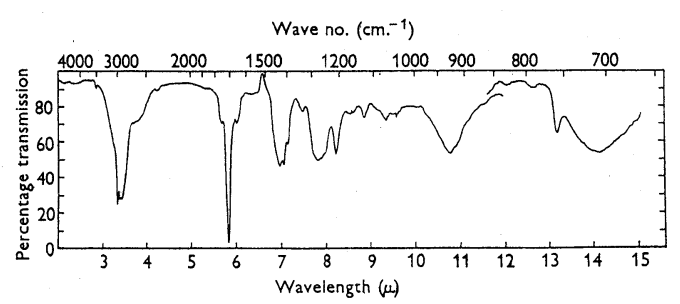

Fig. 2 DHA の赤外吸収スペクトル 


\section{3. 規格・用途}

DHA 高含有食用油に関する規格としては平成 6 年 7 月 1 日に財団法人日本健康 - 栄養食品協会より“健康食 品規格基準の公示”として発表されている。主な用途は 機能性健康食品や食品添加物として, また石鹼等化成品 や化粧品素材として開発されている。一方高純度 DHA は, 将来の医薬品開発に向けて研究用として使用されて いる。

\section{4. 取り扱い上の注意}

酸化されやすいため, 貯蔵, 輸送上, 酸素との接触を
なるべく避け, 遮光, 低温下で行われることが望ましい。 DHA エチルエステル(純度 $98 \%$ )のラットを用いた経口 投与による $\mathrm{LD}_{50}$ 值は $2.000 \mathrm{mg} / \mathrm{kg}$ 体重以上という数値 を示しておりきわめて毒性の低い化合物といえる。

\section{文 献}

1) 矢澤一良, 影山治夫：油化学, 40 (10), 202 (1991)

2) 山口道広ら：油化学, 40 (10), 187 (1991)

3）三澤嘉久, 近藤 寿：酵素工学ニュース, 30 号, 19 (1993)

(平成 6 年 8 月 24 日受理)

\section{第 53 巻第 1 号予定}

\section{巻 頭 言}

植物とかかわって，そして今 藤田 泰宏

総説および総合論文

カルベノイドを用いる高選択的 $\sigma$ 骨格形成反応

奥

わらびの究極発癌物質の合成および DNA との反応

山田 静之ら

カリックスアレーンの立体化学と認識機能

荒木 孝司

生体触媒を用いる光学活性ヒドロキシ酸類の調製法

須貝

威ら

フッ素を分子に組み入れる一合成ブロックの活用一 宇根山健治

電子移動における 14 族元素の $\beta$ 効果とその有機電解合成への応用………........................吉田 潤 一 ケミカルス覚え書き

$N$-フルオロピリジニウム塩誘導体

温井 和則

十字路

アンビフィリシティ

奥 涁

Maxam-Gilbert マーカー

山田 静之

カリックスアレーン

荒木 孝司

Brown-Okamoto $の$ 置換基定数

宇根山健治

REVINDEX, 新しい合成ほか 